\title{
Augmentative and alternative communication: from qualification to speech, language and hearing science clinical practice
}

\author{
Comunicação suplementar alternativa: da formação a atuação clínica \\ fonoaudiológica
}

Carla Ciceri Cesa ${ }^{(1)}$

Helena Bolli Mota ${ }^{(1)}$

(1) Universidade Federal de Santa Maria, Santa Maria, RS, Brasil.

Conflict of interest: non-existent

Received on: February 25, 2017 Accept on: June 28, 2017

\section{Mailing adress:}

Carla Ciceri Cesa

Avenida Dom Cláudio José Gonçalves

Ponce de Leon, 140 ap. 203, torre 2

Coimbra

Vila Ipiranga, Porto Alegre,

Rio Grande do Sul, Brasil

CEP: $91370-170$

E-mail: carlacesafga@yahoo.com.br

\section{ABSTRACT}

Purpose: to investigate the qualification of the speech language and hearing therapists and their clinical performance with Augmentative and Alternative Communication.

Methods: a descriptive, transversal, individual and contemporary study. Data were collected through a questionnaire, filled by twenty-four speech therapists, selected by a convenience sample. Content analysis was chosen for data study.

Results: regarding access to the information media, all speech therapists in the sample presented the initiative to supply the absence of language training with Augmentative and Alternative Communication by different means. Regarding the dual focus on intervention, all speech therapists were favorable to this practice. However, according to experience, they reported resistance from the family, school and other therapists. The results showed two different types of introduction implementation and use of Augmentative and Alternative Communication, predominantly formed by strategies contemplating the pragmatic use of language through the contextualization of significant activities for the user. The other way used the Picture Exchange Communication System.

Conclusion: the speech-language and hearing therapists in the present study inserted different interlocutors in the intervention, guided by implicit or explicit linguistic principles, by theoretical frameworks specific to the area of Augmentative and Alternative Communication knowledge, by global neuromotor elements and, finally, by principles of functionality and general wellness.

Keywords: Speech Language and Hearing Science; Communication; Children's Language; Language; Cerebral Palsy

\section{RESUMO}

Objetivo: investigar a formação do fonoaudiólogo e sua atuação clínica com a Comunicação Suplementar e Alternativa.

Métodos: estudo descritivo, de caráter transversal, individual e contemporâneo. Os dados foram coletados por meio de questionário, preenchido por vinte e quatro fonoaudiólogas, selecionadas por amostra de conveniência. Elegeu-se a análise de conteúdo para estudo dos dados.

Resultados: quanto ao acesso aos meios de informação todas as fonoaudiólogas da amostra apresentaram a iniciativa de suprir a ausência da formação em linguagem com Comunicação Suplementar e Alternativa por diferentes meios. Em relação ao foco duplo na intervenção todos os fonoaudiólogos foram favoráveis a essa prática, entretanto relataram, conforme a experiência, resistência da família, da escola e de outros terapeutas. Os resultados mostraram dois tipos diferentes de implementação da introdução e uso da Comunicação Suplementar e Alternativa, sendo predominantemente por estratégias que contemplem o uso pragmático da linguagem por meio de contextualização de atividades significativas para 0 usuário. A outra forma foi o uso do Picture Exchange Communication System.

Conclusão: os fonoaudiólogos investigados na presente pesquisa inseriram diferentes interlocutores na intervenção e guiaram-se em princípios linguísticos implícitos ou explícitos, em referenciais teóricos específicos à área do conhecimento Comunicação Suplementar e Alternativa, em elementos neuromotores globais e, por fim, em princípios de funcionalidade e bem-estar geral.

Descritores: Fonoaudiologia; Comunicação; Linguagem; Linguagem Infantil; Paralisia Cerebral 


\section{INTRODUCTION}

The American Speech andHearingAssociation (ASHA) ${ }^{1}$ refers that Augmentative and Alternative Communication (AAC) covers all forms of alternative communication in speech, being used to express thoughts, needs, requests and ideas of people with complex communicative needs.

In Brazil, the AAC area has grown, but still needs to expand its number of researchers. The areas of knowledge related to user treatment in the implementation of AAC resources were: speech language and hearing therapy (SLHT), psychology, pedagogy and occupational therapy.The areas of information technology and electrical engineering may also influence or impact with the creation of electronic resources $^{2}$. In another study ${ }^{3}$, two studies in the field of physical therapy with AAC and eleven in speech language and hearing science therapy were identified.

On this aspect, it is noticed that a large number of AAC studies focus on the technological issues of resource, accessibility and portability. The importance is not discussed, but it is pointed out that the main focus is the person with complex communicative need who wants to express their desires and ideas, develop relationships and broaden their social participation ${ }^{4,5}$.

The speech therapist, a professional who works in the area of communication ${ }^{6}$, is able to collaborate even more in the interdisciplinary team, considering theirexpertise in the linguistic aspects involved in the implementation process of an AAC system. The Augmentative and Alternative Communication Committee of the Language Department of the Brazilian Society of Speech-Language and Hearing Science $(\mathrm{SBFa})^{7}$ aims to organize actions that broaden the insertion of the speech therapist in the area, with scientific discussions about theoretical and practical references. Speech-language and hearing science action in AAC practices needs to be further investigated and disseminated through studies based on clinical and scientific evidence. The very diversity of the programs named in Brazil (AAC, Alternative Communication, Expanded Communication, Alternative and Expanded Communication, Increasing and Alternative Communication, Alternative and Facilitating Communication, among others) for the same area of knowledge signals the expansion process. However, we still need a unified Brazilian terminology. In this sense, the present study has the objective of investigating theperformanceprofileand formation of the speech language and hearing therapist who works with $A A C$ in Brazil.

\section{METHODS}

\section{Study guideline}

This is a descriptive, cross-sectional, individual and contemporary study.

\section{Ethical Considerations}

This study complies with the norms of the Research Ethics Committee (CEP) of Universidade Federal de Santa Maria, according to law number 909.685, Presentation Certificate forEthical Appreciation (CAAE) number 38137814.3.0000.5346 and it is in accordance with the norms of the Health Ministry according to 196/96 and 466/12 Resolution.

\section{Participants}

Twenty-four speech therapists working in different states of Brazil composed the convenience sample. Thirteen speech therapists graduated in the state of Rio Grande do Sul, eight in São Paulo, one in Minas Gerais, one in Santa Catarina and one in Rio de Janeiro. Table 1 shows the sociodemographic variables of the speech therapists profile sample.

\section{Collection Instrument}

The collection instrument was developed for this research. This is a questionnaire with twenty questions (APPENDIX 1) with open and closed questions about AAC formation and experience. It is noteworthy that an initial pilot study was conducted in which the same questionnaire was applied with two randomly chosen speech therapists to verify the suitability of the instrument, and it was verified that the instrument met the research objective.

\section{Sample Selection and Data Collection Procedure}

The invitation to participate in the research was conducted via e-mail to forty-two speech therapists from different Brazilian states, selected by convenience sampling. All speech therapists were duly informed about the purposes of the research. The telephone contact was also carried out.

This convenience sample was generated by three different means: (a) via the professional contact network of the first author who has been working in the clinical 
Table 1. The sociodemographic variables of the speech therapists profile sample

\begin{tabular}{|c|c|c|c|c|c|}
\hline Subject & Age & $\begin{array}{l}\text { Formation } \\
\text { time (years) }\end{array}$ & $\begin{array}{c}\text { AAC time } \\
\text { experience } \\
\text { (years) }\end{array}$ & $\begin{array}{c}\text { State } \\
\text { inBrazil }\end{array}$ & Currentoccupation \\
\hline SLHT 1 & 43 & 19 & 19 & RS & Clinic \\
\hline SLHT 2 & 57 & 37 & 37 & SP & Teaching, clinical supervision and research \\
\hline SLHT 3 & 42 & 22 & 6 & SP & Member of the Health Office team \\
\hline SLHT 4 & 44 & 23 & 21 & SP & $\begin{array}{l}\text { Clinic, teaching, clinical supervision and staff member } \\
\text { of the Education Office }\end{array}$ \\
\hline SLHT 5 & 32 & 7 & 7 & RS & Clinic \\
\hline SLHT 6 & 37 & 9 & 9 & RS & Clinic \\
\hline SLHT 7 & 36 & 11 & 11 & RS & Clinic \\
\hline SLHT 8 & 31 & 10 & 8 & RS & Clinic \\
\hline SLHT 9 & 42 & 18 & 5 & RS & Clinic \\
\hline SLHT 10 & 39 & 15 & 14 & RS & $\begin{array}{c}\text { Clinic, clinical supervision, researcher and guest } \\
\text { teacher }\end{array}$ \\
\hline SLHT 11 & 25 & 4 & 6 & RS & $\begin{array}{c}\text { Clinic, researcher and staff member of the Education } \\
\text { Office }\end{array}$ \\
\hline SLHT 12 & 40 & 18 & 10 & RS & Clinic and clinical supervisor \\
\hline SLHT 13 & 37 & 14 & 6 & RS & Member of the Health Office team \\
\hline SLHT 14 & 39 & 17 & 17 & RS & Clinic \\
\hline SLHT 15 & 53 & 32 & 28 & RJ & Clinic and Teaching \\
\hline SLHT 16 & 30 & 7 & 1 & $M G$ & Teaching, clinical supervision and research \\
\hline SLHT 17 & 40 & 17 & 10 & RS & Teaching and research \\
\hline SLHT 18 & 22 & 2 & 1 & RS & Clinic, clinical supervision and research \\
\hline SLHT 19 & 28 & 4 & 6 & SC & Clinic and clinical supervision \\
\hline SLHT 20 & 51 & 30 & 25 & SP & Teaching and research \\
\hline SLHT 21 & 27 & 6 & 6 & SP & Clinic, teaching and research \\
\hline SLHT 22 & 35 & 15 & 9 & SP & $\begin{array}{l}\text { Teaching, research and staff member of the } \\
\text { Education Office }\end{array}$ \\
\hline SLHT 23 & 52 & 30 & 25 & SP & Teachingandresearch \\
\hline SLHT 24 & 28 & 1 & 1 & SP & Clinic \\
\hline
\end{tabular}

$\mathrm{AAC}=$ Augmentative and Alternative Communication

SLHT = Speech Language and Hearing therapist

$M G=$ Minas Gerais

$\mathrm{RJ}=$ Rio de Janeiro

$\mathrm{RS}=$ Rio Grande do Sul

$\mathrm{SC}=$ Santa Catarina

$\mathrm{SP}=$ São Paulo

area of neurofunctional speech language and hearing therapy with AAC use for 18 years; (b) via professional contacts arising from this initial network of contacts and (c) from professional contacts spontaneously shared by a member of the examining board in the qualification of the thesis (the present article composes one of the studies of the final thesis).

The term of free and informed consent (TCLE) and a questionnaire specially developed for this study (APPENDIX 1) was personally delivered and/or sent via email to speech therapists who expressed an interest in collaborating. The choice of delivery method of the two documents was agreed with each participant. After this first moment, both documents were received signed, completed and returned to the first researcher by two different modalities: in person or by email with both scanned documents.

Included in the research were professionals with clinical experience in AAC who accepted to participate by signing the TCLE and that sent the questionnaire within the deadline stipulated by the researcher. The speech therapists who did not send the questionnaire or who did not agree to participate in it were excluded.

The period of data collection was from January 7th, 2015 to August 19th, 2015. 


\section{Content Analysis Procedure}

Data were studied by the content analysis method based on Minayo (2010) ${ }^{8}$. The four categories of analysis were extracted from the reading of the questionnaire responses, namely: (a) means of access to information on AAC; (b) dual focus on the intervention (user and other interlocutors); (c) resistance to adherence of the interlocutors in the introduction and use of AAC and (d) therapeutic strategies.

The categories were evaluated by two speech language andhearing judges. According to Fagundes $(2015)^{9}$, the acceptable comparative parameter for concordance occurrences should be equal to or greater than $70 \%$. The concordance index in this study ranged from $75 \%$ to $100 \%$.

\section{RESULTS}

Twenty-four Speech-Language hearing therapists, Brazilian, female, accepted to participate in the study. Of these, twenty-three professionals reported having attended to children with cerebral palsy (CP) using AAC. A speech therapist (SLHT16) has attended only to adults with brain injury with AAC.

The average age of the speech therapists was 38 years old, with 15 year average formation time and an average of 12 years of experience with AAC. Nine speech therapists have studied in federal universities, covering the states of Rio Grande do Sul, Minas Gerais and São Paulo and 15 in private institutions, covering the states of Rio Grande do Sul, Santa Catarina, Rio de Janeiro and São Paulo.

At the time of collection, the interviewees worked in different fields of speech language and hearing science, such as clinical care, teaching, research, as a member of the health office and as a member of the city or state education department.

The results will be arranged according to the four categories extracted during content analysis.

\section{Means of access to information on AAC}

Speech language and hearing therapists SLHT5, SLHT6 and SLHT11 were supervised in an extracurricular internship environment during the graduation period. SLHT5 adds that he/she also learned by observing speech therapists attending the extracurricular internship at a philanthropic institution.

Two speech therapists (SLHT9 and SLHT19) did not take courses, supervision (advice), research or other means of access to information on the subject.
Speech therapists SLHT5, SLHT20 and SLHT23 responded explicitly that they also learned from their own clinical experience.

The data collected, regarding this category of analysis, indicate that the search for means of access to information on how to intervene with AAC wasbased, above all, on their own initiative. Figure 1 shows the means of access to AAC information:

\section{Dual focus intervention (user and other partners)}

Twenty-two speech therapists claim to work with a dual focus on AAC intervention, inserting other significant interlocutors for the child as well as other people responsible for them such as caregivers, friends and other therapists, in addition to the family and school.

SLHT 18 works in a shelter that welcomes children with severe neurological impairments in which the State is their guardian, and the family is not present. SLHT2O has not mentioned anything about this aspect.

Through the questionnaire answered by speech therapists, the following representative examples regarding the aspects of the dual focus category in the intervention were selected:

SLHT 5: "Family and society adapt to the new, to a" different "way of communicating (...). Persistence and dialogue are what usually makes the difference in the process."

SLHT 6: "The acceptance and systematization of the use by the family. I believe continuous conversations and practical examples and engagement in the goals have greater adherence."

SLHT 16: "Sincerely, you participate if you have the interest. The patient, the therapist, and the third person vary. I prefer it is someone with a lot of contact with the patient (family member, friend and I or caregiver). This person is not always willing or motivated, and in this case I am looking for a well-motivated person (even if he/she does not have so much contact) to help me to motivate people closer to the patient. I also explore other professionals who attend the patient or the teacher."

The data indicate that the therapeutic strategy of speech therapists to include families and other interlocutors in the therapeutic process aim at the generalization of AAC use to naturalistic environments and not only during the speech therapy session. 


\begin{tabular}{|l|c|c|}
\hline Means of access to AAC information & Occurrence & $\begin{array}{c}\text { Speech Language and Hearing } \\
\text { Therapists }\end{array}$ \\
\hline Specific congresses in the AAC area & 3 & SLHT 1, 10 and 23 \\
\hline $\begin{array}{l}\text { Lecture at non-specific congresses in the AAC area, in seminars and other } \\
\text { scientific events }\end{array}$ & 3 & SLHT 8,11 and 18 \\
\hline Various international courses & 4 & SLHT 2,15,20 and 23 \\
\hline International course on Bliss communication system & 1 & SLHT 2 \\
\hline Extension courses & 13 & $\begin{array}{c}\text { SLHT 1, 6, 7, 8, 10, 12, 13, } \\
14,15,16,17,20 \text { and 23 }\end{array}$ \\
\hline State university improvement course & 1 & SLHT 24 \\
\hline AAC specialization course in private university & 2 & SLHT 4 \\
\hline $\begin{array}{l}\text { Specific course of Picture Exchange Communication System (PECS) } \\
\text { methodology }\end{array}$ & 1 & SLHT 7 and 22 \\
\hline Participation in research group and work group linked to a state university & 1 & SLHT 3 \\
\hline Production of articles in his/her own research line in state university & 3 & SLHT 23 \\
\hline Supervision (advice) & 3 & SLHT 12, 16 and 21 \\
\hline Internship and supervision during graduation & SLHT 12, 16 and 21 \\
\hline
\end{tabular}

$\mathrm{AAC}==$ Augmentative and alternative Communication

$\mathrm{SLHT}=$ Speech Language and Hearing Therapists

Figure 1. Means of accessing information from AAC by therapists

\section{Resistance to the adhesion of interlocutors in the introduction and use of AAC}

Twenty-one speech therapists have reported that in their experiences there is resistance from families in the introduction and use of AAC. It is recorded that many professionals have also stated that there is resistance from educators in using the communicative resource in the school environment.

As already discussed in the previous category, SLHT18 operates in a shelter without having the children's family present. SLHT 20 and SLHT21 did not mention anything about this aspect.

Some representative examples from the interviews on the category of resistance to family membership will be presented below:

SLHT 2: “(...) to favor and maintain adherence and motivate the use, in addition to demystify that it inhibits speech."

SLHT 3: "It depends on the motivation, educational preparation and teacher consciousness".

SLHT 4: "The greatest difficulty is other people, not the child".

SLHT 10: "I believe that it is family and professionals involved who do not know the Augmentative and Alternative Communication and its benefits and they present a certain prejudice with the use of this system. I also realize that some schools (leadership and teachers) are resistant to applying Augmentative and Alternative Communication in the context and / or school routine."

SLHT 13: "The real engagement of the family so that the child can be the subject of their communication also in the family environment".

\section{Therapeutic Strategies}

The results of this category were grouped into subcategories, also created from the data analyzed in the interviews. A single framework has been developed that also presents the principles used to guide clinical performance.

A speech therapist (SLHT 19) did not answer the specific question related to the therapeutic strategies and three speech therapists (SLHT 3, 9 and 18) did not answer the question about the therapeutic principles.

Below are some of the significant samplesselected from the categories of therapeutic strategies:

SLHT 1: "(...) that the child perceives the effect that the resource of the Augmentative and Alternative Communication provides and the pleasure of communication".

SLHT 2: "Contextualized interest activities to the user and their environment, involving the family. 
Games, photos and history of personal and family life, newspapers, story books, magazines, games, dramatic games, music, singing, talk, discussion rounds (...)".

SLHT 5: "I tend to respect their choices so that they can perceive they can be understood. So, if in the alternative communication you want to drink water, I try to give you a glass of water. So, I work with action and reaction".

SLHT 11: "(...) valuing activities of daily living and all episodes of social interaction to introduce strategies of Augmentative and Alternative Communication. In addition to carrying out the above strategies, family members are directed to maintain a daily routine of at least 45 minutes of stimulation of activities worked in speech language and hearing therapy".

SLHT 14: "To be able to listen to the patient and their family, to observe how communication is established between the patient and his/her family and social environment, and to intervene to facilitate it ...".

SLHT 16: "I try to simulate real communication situations. In fact, I look for the top everyday situations".

SLHT 20: "The important thing is to show that everyone can better express their desires and needs".

SLHT 23: "Strategies are developed from the basic vocabulary of the client in different situations of his / her routine, increasing the use in themes of interest, as well as the involvement in the productions of narrative and other types of texts. Strategies are critical to the functionality of the graphic system and the resources that should be used. The strategies should predict a change of environment, changes of tasks and changes of known and unknown interlocutors".

In relation to the principles guiding therapeutics, there were four different principles, not necessarily mutually exclusive:

\section{$1^{\circ}$ Theoretical principles of language acquisition, subject and learning}

There was an explicit adoption of different theoretical lines of language acquisition (interactionism and discursive)and of how the process of active learning (constructivism) as well as subject (psychoanalysis) take place.

\section{$2^{\circ}$ Specific theoretical principles to the area of $A A C$ knowledge}

National and international authors were mentioned as references, namely: Deliberato, Manzini and Deliberato, Paura and Light and McNaughton.

The Picture Exchange Communication System (PECS) method was also cited.

\section{$3^{\circ}$ Explicit linguistic principles}

The relevance of pragmatics, communicative intention, types of inquiry that facilitate communication, dialogic processes, verbal comprehension skills, the need to develop linguistic competence to increase communicative ability, expressive means and the multimodal communication system were mentioned.

\section{$4^{\circ}$ Global Neuromotor Principles}

Global motor aspects, acuity, visual and auditory perception, visual motor coordination were also considered.

\section{$5^{\circ}$ Principles of Functionality}

It was mentioned the use of the International Classification of Functioning (ICF) to evaluate communication in accordance with global health policies, qualifying capacity measures, environmental and personal factors for the general health process.

A speech therapist (SLHT 20) says that her first guideline is more focused on socio-anthropological issues, as the example elucidates: "first the principle that everyone has the right to communicate."

\section{DISCUSSION}

The different means of access to AAC information by the speech therapists of this research sample evidence the necessity of the inclusion of the subject in the graduation. The findings corroborate the affirmation of study ${ }^{10}$ that recommends includinga class specialized in AACin the curriculum with laboratory practices or, at least, to contemplate it in some teaching plan of the language area.

An example of this theoretical gap is observed in Figure 2, which presents the principles that guide the therapeutic strategies of speech language and hearing therapists. Some of the principles do not 


\begin{tabular}{|c|c|c|c|c|c|}
\hline \multicolumn{3}{|c|}{ PRINCIPLES } & \multicolumn{3}{|c|}{ STRATEGIES } \\
\hline Types & Occurrences & SLHT & SLHT & Occurrences & Types \\
\hline $\begin{array}{l}\text { Discursive approach considering } \\
\text { language as constitutive of itself }\end{array}$ & 1 & SLHT2 & $\begin{array}{l}\text { SLHT } 1,4, \\
14 \text { and } 20 \\
\end{array}$ & 4 & $\begin{array}{l}\text { Motivate and favor the discovery of } \\
\text { pleasure in communicating }\end{array}$ \\
\hline $\begin{array}{c}\text { Interactionist and psychoanalytic } \\
\text { approach }\end{array}$ & 1 & SLHT4 & $\begin{array}{l}\text { SLHT 2, 3, } \\
4,5,6,7 \\
10,11,13 \\
16,17,21 \\
\text { and } 23\end{array}$ & 13 & $\begin{array}{l}\text { Create contextual activities and of } \\
\text { interest to the AAC user. } \\
\text { Simulate everyday activities. }\end{array}$ \\
\hline $\begin{array}{l}\text { Produce objective questions, as } \\
\text { well as responding immediately to } \\
\text { requests from children }\end{array}$ & 1 & SLHT5 & $\begin{array}{l}\text { SLHT } 15, \\
18,21,22 \\
\text { and } 24\end{array}$ & 5 & $\begin{array}{l}\text { Focused on high and low technology } \\
\text { resources }\end{array}$ \\
\hline $\begin{array}{c}\text { It considers cognition, } \\
\text { comprehension and expressive } \\
\text { language }\end{array}$ & 5 & $\begin{array}{l}\text { SLHT } 8,10, \\
15,1 \text { and } 22\end{array}$ & $\begin{array}{l}\text { SLHT 8, } 9 \\
\text { and } 12\end{array}$ & 3 & Customized according to the AAC user \\
\hline $\begin{array}{l}\text { It considers motor, sensory, auditory, } \\
\text { visual aspects and visual motor } \\
\text { coordination }\end{array}$ & 7 & $\begin{array}{l}\text { SLHT 5, 6, } \\
10,12,15, \\
16 \text { and } 17\end{array}$ & SLHT 3 & 1 & $\begin{array}{l}\text { It starts with interlocutors who have } \\
\text { more use acceptance }\end{array}$ \\
\hline $\begin{array}{l}\text { Favor social relationships, attempt to } \\
\text { communicative intention in playing } \\
\text { and dialogue }\end{array}$ & 4 & $\begin{array}{l}\text { SLHT10,12, } \\
17 \text { and } 20\end{array}$ & All SLHTS & 24 & Include the interlocutors \\
\hline $\begin{array}{l}\text { Encourage the discovery of pleasure } \\
\text { in communicating }\end{array}$ & 1 & SLHT11 & SLHT 7 & 1 & $\begin{array}{l}\text { Gradual extension of symbols } \\
\text { expanding vocabulary }\end{array}$ \\
\hline Constructivist Approach & 1 & SLHT13 & SLHT 16 & 1 & $\begin{array}{l}\text { Use during the assistancealong with } \\
\text { the physiotherapist }\end{array}$ \\
\hline $\begin{array}{l}\text { Listening to the patient and the family, } \\
\text { in addition to considering the dialogic } \\
\text { processes }\end{array}$ & 1 & SLHT14 & & & \\
\hline $\begin{array}{l}\text { Level of independence; it considers } \\
\text { the International Classification } \\
\text { of Functioning (CIF); right to } \\
\text { communicate }\end{array}$ & 3 & $\begin{array}{l}\text { SLHT 2, } 16 \\
\text { and } 20\end{array}$ & & & \\
\hline Pragmatic Principles & 1 & SLHT16 & & & \\
\hline $\begin{array}{c}\text { Based on theoretical references of the } \\
\text { AAC specific area }\end{array}$ & 4 & $\begin{array}{l}\text { SLHT19, 21, } \\
23 \text { and } 24\end{array}$ & & & \\
\hline $\begin{array}{c}\text { Linguistic competence to increase } \\
\text { communicative ability }\end{array}$ & 1 & SLHT 23 & & & \\
\hline Multimodal communication system & 1 & SLHT 23 & & & \\
\hline $\begin{array}{l}\text { A method called Picture Exchange } \\
\text { Communication System (PECS) }\end{array}$ & 4 & $\begin{array}{l}\text { SLHT 1, 7, } \\
22 \text { and24 }\end{array}$ & & & \\
\hline
\end{tabular}

$\mathrm{AAC}=$ Augmentative and Alternative Communication

SLHT $=$ Speech Language and Hearingtherapist

$\mathrm{CIF}=$ International Classification of Functioning, Disability and Health

PECS $=$ Picture Exchange Communication System

Figure 2. Principles guiding AAC assistance and therapeutic strategies

fit methodologically with the exemplified strategy, according to SLHT 7 and SLHT 22 samples, considering the PECS ${ }^{11-13}$ method reported in the questionnaire.

The emergence of resources as therapeutic strategies shows that the definition of what user-focused strategies are seems to be not clear enough, since the operational domain is what covers this aspect. However, the answers that mention the customization according to the user are very comprehensive to be able to understand in practice what the real strategies of AAC implementation are.

In the present research, the therapeutic strategies evidenced different approaches in the introduction and use of AAC. There is a predominance of the strategy that contemplates the pragmatic use of language through contextualization of meaningful activities for the user. The contribution in cognitivist concepts was also mentioned as a theoretical foundation. Finally, the other approach was the use of a communication program 
known as Picture Exchange Communication System (idealized by Bondy and Frost in 1994) ${ }^{12,13}$, which has its application based on Applied Behavior Analysis (ABA). In a study ${ }^{10}$ with speech language and hearing therapists about their theoretical bases in the AAC treatment, socio-interactionist, behavioral and cognitive approaches were found, corroborating with the data of the present study.

Despite having different theoretical views, the speech-language and hearing therapists report difficulties and even failure to implement AAC with the family and / or school. Thus, it can be seen that only the research variable "theoretical line" does not support the generalization of use for daily life. Therefore, the proactive attitude and willingness of the interlocutor to communicate with the child must be considered. International researchers ${ }^{14}$ have disclosed in the Special Interest Groups (SIG 12), apublication on AAC in the American Speech and Hearing Association (ASHA), evidence that there is indecision by the family and/or professionals to implement AAC strategies. So, it is encouraged the motivation for family empowerment in this implementation process but supported by professionals.

In this research it is inferred that families do not use the resource because it demands will, time and persistence in using it with the children. In fact, the genuine desire was for children to use oral language, not the alternative one.

As far as the interlocutors in the educational environment are concerned, there is a lack of formation and continuous consultation in AAC. Another aspect to be considered, at the time of the selection, is teachers who have real will and profile to work with children with complex communication needs, in addition to the presence of monitors and reduced number of students per class.

In the educational context, the success of the accompaniment of a speech therapist with a teacher in a field survey ${ }^{15}$ favored an increase in AAC use, including itas a tool for evaluation and teaching of pedagogical concepts.

Studies on user dialogue and other interlocutors are the subject of several studies ${ }^{16-19}$. On this subject, a case report ${ }^{17}$ considered a longitudinal methodology, with a baseline (BL), a monitoring plan and a follow-up of the mother and child with $\mathrm{CP}$ dyad. We used a material developed in the doctoral program of the first author of the study (op. cit), developing an individualized program of AAC for mothers of children with $C P$.
It is seen that guiding points of more functional communication intervention programs are being researched and disseminated.

An increase of the linguistic studies in AAC is noticed, considering the use of the language and the communication in the daily life. An example of this is the list of 269 words, classified in 18 semantic and syntactic themes developed by Brazilian authors ${ }^{18}$ for health and education professionals, but especially for speech language and hearing therapists in order to make the creation of communication boards and their use more functional.

Another study ${ }^{19}$ directed to the evaluation of syntax, also with $A A C$, has a great relevance to extend the communicative abilities. Children with complex communicative needs tend to use a single symbol (miniature, label, graphic symbol, photograph, drawing, etc.), remaining in a vertical structure. In order to develop a narrative we need to develop a horizontal structure in which different symbols are used and produced by different communicative means ${ }^{19}$, favoring the linguistic competence to broaden communicative abilities ${ }^{5}$.

\section{CONCLUSION}

It is necessary to include in the pedagogical political projects of speech-language and hearing sciencecourses, theoretical classes of clinical observation and practical classes (curricular trainings) with intervention in language with AAC. The speech-language and hearing therapists insert different interlocutors in the intervention with $A A C$ and are guided by implicit or explicit linguistic principles, according to their written discourse, by specific theory reference to the AAC knowledge area, by global neuromotor elements and, finally, by principles of functionality and general well-being.

\section{REFERENCES}

1. American Speech and Hearing Association - ASHA: [acessoem 2016 Ago 16]. Disponível em: http:// www.asha.org.

2. Manzini EJ. Formação de pesquisadores para a área de Comunicação Alternativa. In: Nunes LROP, Pelosi MB, Walter CCF. (orgs.) Compartilhando experiências: ampliando a comunicação alternativa. Marília: ABPEE; 2011. p. 139-60.

3. Cesa CC, Mota HB. Augmentative and alternative communication: scene of Brazilian journal. Rev. Cefac. 2015;17(1):264-9. 
4. Light J, McNaughton D. Putting people first: Re-thinking the role of technology in Augmentative and Alternative Communication intervention. Augment Altern Commun. 2013;29(4):299-309.

5. Light J, McNaughton D. Communicative Competence for Individuals who require Augmentative and Alternative Communication: A New Definition for a New Era of Communication? Augment Altern Commun. 2014;30(1):1-18.

6. Brasil. Presidência da República. Lei $n^{\circ} 6965$ de 9 de dezembro de 1981. Dispõe sobre a regulamentação da Profissão de Fonoaudiólogo, e determina outras providências.

7. Sociedade Brasileira de Fonoaudiologia SBFa. [acesso em 2016 Ago 07]. Disponível em: URL: http://www.sbfa.org.br/portal/ pg.php?id=comite\&ttpg =COMIT\%CA\%20DE\%20 COMUNICA\%C7\%C3O\%20SUPLEMENTAR\%20 E\%20ALTERNATIVA\&tpc $=$ cinza

8. Minayo MCS. O desafio do conhecimento: pesquisa qualitativa em saúde. 13a.ed. São Paulo: Hucitec; 2010.

9. Fagundes AJFM. Descrição, definição e registro de comportamento. 17a ed. São Paulo: EDICON; 2015.

10. Cesa CC, Kessler TM. Comunicação alternativa: teoria e prática clínica. Distúrb. Comun. 2014;26(3):493-502.

11. Oliveira GC, Rosa VSV, Carvalho W, Freitas EF. Considerações da aplicação do método PECS em indivíduos com TEA. EVS. 2015;42(3):303-14.

12. Bondy AS, Frost LA. The Picture Exchange Communication System. Focus Autism. Other. Dev. Disabl. 1994 [artigo na internet] 9(3):1-19 [acesso em 2016 Ago 07]. Disponível em: URL: http:// pecs-canada.com/Brochures/pecsfocuspdf.pdf

13. Bondy A. PECS: Potential benefits and risks. Behav Anal Today. 2001;2:127-32.

14. Smith AL, Barton-Hulsey A, Nwosu N. AAC and Families: dispelling myths and empowering parents. perspectives of the ASHA Special Interest Groups - SIG 12. 2016;1:10-20.

15. Silva RLM, Silva SSC, Pontes FAR, Oliveira AIA, Deliberato $D$. Efeitos da comunicação alternativa na interação professor-aluno com paralisia cerebral não-falante. Rev. Bras. Ed. Esp. 2013;19(1):25-42.

16. Deliberato $D$. Percepção de mães e fonoaudólogos a respeito do uso de Sistemas Suplementares e Alternativos de Comunicação. In: Nunes LROP, Pelosi MB, Walter CCF. (orgs.) Compartilhando experiências: ampliando a comunicação alternativa. Marília: ABPEE; 2011. p.57-69.

17. Manzini MG, Martinez CMS, Almeida MM. Programa individualizado de comunicação alternativa para mães de crianças com paralisia cerebral não oralizadas. Distúrb. Comum. 2015;27(1):26-38.

18. Paura AC, Deliberato D. Estudo de vocábulos para avaliação de crianças com deficiência sem linguagem oral. Rev. Bras. Ed. Esp. 2014;20(1):37-52.

19. Deliberato $D$. Sistemas suplementares e alternativos de comunicação nas habilidades expressivas de um aluno com paralisia cerebral. Rev. Bras. Ed. Esp. 2011;17(2):225-44. 


\section{APPENDIX 1 - Questionnaire for voluntary speech language and hearing therapists}

Identification information

Name:

Age:

Institution of graduation:

Time of formation in Speech Language and Hearing Therapy:

Working time with Augmentative and Alternative Communication:

Approximately how many patients with Cerebral Palsy and Augmentative and Alternative Communication have you attended:

Currently you have which role (s):

( ) Therapist

( ) Clinical supervisor

( ) Teacher

( ) Teacher and researcher

( ) Researcher

( ) Comprises technical staff of Health Office (State or City?)

( ) Comprises technical staff of the Education Office (State or City?)

( ) other(s):

1. How is your assessment in Augmentative and Alternative Communication?

2. Do you deal with other types of patients besides the ones with cerebral palsy? What is the predominant population in your experience with Augmentative and Alternative Communication?

3. In which type of institution do you work (private, public or philanthropic)? Do you provide home care in long-term care facilities for the elderly and / or in a hospital?

4. Have you taken any course (formation) in Augmentative and Alternative Communication?What? In what year?

5. What principles do you use to guide your clinical performance in Augmentative and Alternative Communication?

6. Who participates in the intervention in Augmentative and Alternative Communication? How?

7. How do you introduce the Augmentative and Alternative Communication?

8. What strategies do you use to develop the use of Augmentative and Alternative Communication?

9. Do you use high and / or low technology?

10. Which resource (s) do you use? (Tablet, vocalizer, board, isolated cards, key chains, types of software, etc.)

11. What kind of symbolic representation type (s) do you use? (miniatures, real objects, photography, drawings, graphic systems, etc ....)

12. If you use graphic systems in Augmentative and Alternative Communication? Which ones do you use? Justify your answer. (Picture Communication Symbols - PCS, Blissymbols, Pictogram-Ideogram Communication - PIC, ARASAAC, ImagoAnaVox, Rebus, writing, etc.)

13. What are the biggest challenges in Augmentative and Alternative Communication clinic and what do you do to address these challenges?

14. What difficulties do you face during communication with children with cerebral palsy using Augmentative and Alternative Communication?

15. During children's assistance what do you do to help them communicate?

16. How do the topics developed in the conversations with the children usually come up?

17. How do you perceive the communicative profile of children with cerebral palsy?

18. Can the child easily associate the resource (tablet, low-tech board) as a means of communication?

19. What is your experience with the use of Augmentative and Alternative Communication in the school environment?

20. Free comments. 